\section{Päättäväisesti ilmastoneutraaliksi}

Pantsar, Mari \& Keronen, Jouni (2019). Tienhaarassa. Johtajuus ilmastonmuutoksen aikakaudella. Docendo. 280 sivua.

TIENHAARASSA on vavisuttava teos. Se havainnollistaa monitieteiseen tutkimustietoon perustuen sen tienhaaran, jossa yhteiskunnat ja kansalaiset elämäntapoineen ovat.

Ensi kertaa maailman historiassa ihmisen vaikutusvoima tulevaisuuteen on ylittänyt luonnonvoimat. Tämä ilmenee siten, että ihmisten vaikutuspiirin ulkopuolista luontoa ei enää ole. Luonnon ja kulttuurin välisen jakolinjan poistumisen tiedostaminen haastaa ihmistä kytkeytymään itsensä ulkopuolella olevaan todellisuuteen aiempaa vastuullisemmin.

Tulevaisuuden laatu on meidän ihmisten käsissä enemmän kuin koskaan aikaisemmin maapallolla. Ihminen on samalla sekä ongelma että ratkaisu.

Kapitalismista on kehittynyt koko planeetan kaikkine kansoineen ja tuotantoresursseineen lävistävä maailmanjärjestelmä. Sen ominaispiirteisiin kuuluu, että elintason parantaminen lepää talouskasvun varassa. Talouskasvu perustuu ihmisen panoksiin ja luonnonvarojen hyödyntämiseen.

Yhteiskuntien edistymisen osoittimeksi otettu bruttokansantuote osoittaa muutoksia taloudellisessa toimeliaisuudessa. Myönteiseksi muutokseksi on totuttu mieltämään kaikki se, mikä kasvattaa taloutta.

\section{PERUUTTAMATTOMIEN MUUTOSTEN KYNNYKSELLÄ}

Vuonna 1972 Rooman klubi osoitti, että rajaton kasvu rajallisten luonnonvarojen maailmassa on mahdotonta. Nyt on ymmärretty, että maapallon rajalliset luonnonvarat, päästöjen sitomiskapasiteetti ja elämää ylläpitävän luonnon monimuotoisuuden säilyttäminen asettavat ehtoja taloudelliselle toimeliaisuudelle.

Vaikkapa tietotalous on aineettomampaa kuin raskaaseen teollisuuteen perustuva talouskasvu. Mutta tietotalouskin hyödyntää yhteiskunnan infrastruktuuria ja tarvitsee energiaa. Ilman sähköä, liikettä ja lämpöä ei talouskasvuun viittaavaa inhimillistä toimeliaisuutta juuri ole olemassa.

Kaikki ei käy, mikäli halutaan, että elinkelpoiset olot säilyvät kotiplaneetallamme. Toimilla on kiire, sillä maapallolla ollaan peruuttamattomien muutosten kynnyksellä, joiden vaikutuksia ei enää ole mahdollista ottaa haltuun. Itse itseään kiihdyttävän ilmastonmuutoksen todennäköisyys kasvaa vuosi vuodelta.

\section{PAKKO JOHTAISI \\ KIELTOYHTEISKUNTAAN}

Sitran johtaja Mari Pantsar ja dosentti Jouni Keronen lähestyvät ilmastonmuutosta systeemi-

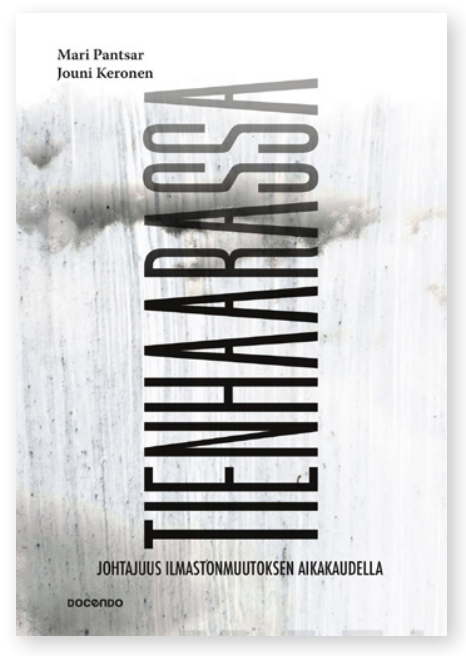

ongelmana. Systeemiongelma edellyttää systeemin muuttamista, mikä haastaa ilmastojohtajuutta ja politiikkatoimia, sillä käytännössä ilmastojärjestelmään vaikuttamisessa ratkaisut ovat samaan aikaan yksittäisten ihmisten, yritysten ja valtioiden käsissä. Mikään elämän osa-alue ei jää systeemimuutoksessa piiloon, vaan kukin kääntyy uuteen asentoon, kun ilmastonmuutos pysäytetään - vapaaehtoisesti tai pakosta yrittämällä, jotta haitat eivät kasvaisi sietämättömän suuriksi.

Pakon edessä toiminen johtaisi kirjoittajien mukaan kieltoyhteiskuntaan: yritysten toimintaa pitäisi merkittävästi rajoittaa ja kansalaisten kulutustottumuksia radikaalista ohjailla.

Ilmastojärjestelmä kytkeytyy muihin luonnon ekosysteemeihin. Kirjoittajat toteavat, että "90 prosenttia ihmisen aiheuttamasta ilmastojärjestelmän lämpenemisestä päätyy meriin”. Ensimmäinen kokonainen luonnon ekosysteemi, joka nykyisen kehityskulun 
jatkuessa poistuu maapalloltamme meriveden lämpenemisen ja happamoitumisen seurauksena, on korallit.

Systeemisen ymmärryksen merkitystä korostaa se, että ekologiset ja sosiaaliset haasteet lomittuvat ja kytkeytyvät toisiinsa. Koralleilta saa päivittäisen ruokansa 250-500 miljoonaa ihmistä, jotka joutuvat jättämään asuinseutunsa ruoan lähteen häviämisen myötä. Korallien kuolema on siten myös skandinaavinen haaste elämän edellytysten murtumisen tuottaman maahanmuuton muodossa.

\section{KANSALAISTEN OSALLISUUS ON TAATTAVA}

Ilahduttavaa Tienhaarassa on ratkaisukeskeisyys. Ongelmat tunnistetaan, mutta niiden pariin ei jäädä piehtaroimaan vaan sanoitetaan reittejä kohti ratkaisuja. Ratkaisukeskeisyydestä kertoo vähälle huomiolle jääneiden, mutta oleellisien asioiden, kuten aurinkoenergian potentiaalin, esiin nostaminen: "Aurinko säteilee maapallon maa-alueille arvion mukaan yli 1400-kertaisesti ihmisen tarvitseman energian.” Eikä ilmastoneutraaliin yhteiskuntaan siirtyminen välttämättä ole taaksepäin menemistä - kunhan liikkeelle lähdetään kirjaimellisesti hyvän sään aikana. Systeemimuutos voi olla siirtymistä kohti parempaa maailmaa.

Ilmastoneutraali hyvinvointiyhteiskunta on kansalaisille puhtaampi ja terveellisempi. Hiilineutraaliin talouteen siirtyminen voi vähentää kirjoittajien mukaan pienhiukkaspäästöistä johtuvia ennenaikaisia kuolemantapauksia yli 40 prosentilla ja terveyshaittoja 200 miljardilla eurolla vuodessa maapallolla. Oleellista on toteuttaa siirtymä ilmastoneutraaliin yhteiskuntaan reiluilla tavoilla ja siten, että kansalaiset kokevat olevansa osallisia paremman huomisen tekemisessä.

Miksi sitten planetaariset asiat pitäisi ottaa todesta pienessä Suomessa? Maailman rikkain kymmenys ihmisistä aiheuttaa puolet maailman hiilipäästöistä. Siihen kymmenykseen me suomalaiset kuulumme. Voimme omilla toimillamme merkittävästi muuttaa kehityksen suuntaa sotien jälkeistä yhteiskunnallista murrosta suuremmassa systeemimuutoksessa.

Suomen mahdollisuus on siinä, että joka tapauksessa joku rakentaa ratkaisut planeetan kokoiselle siirtymälle kohti hiilineutraaleita yhteiskuntia. Ratkaisuja kysellään tulevaisuudessa edelläkävijöiltä, sillä ilmastonmuutos on huomattavasti nykyistä kuumempi puheenaihe jo kymmenen vuoden päästä.

\section{SUOMI VOI OLLA SUUNNÄYTTÄJÄ}

Tienhaarassa kannustaa tarttumaan toimeen ja tekemään tulevaisuudesta sellaista, jossa arvokkaan ja ainutkertaisen ihmisen on mahdollista elää täysipainoista hyvää elämää. Ilmastonmuutoksen pahimmilta seurauksilta on mahdollista välttyä, mutta vain kansalaisten, kansalaisyhteiskunnan, yritysten ja julkisen sektorin yhteistoiminnalla, jota tukee määrätietoinen politiikka.

Median rooli on keskeinen, ja sen mahdollisuuksiin kirjoittavat uskovat. Samalla he tiedostavat, että keinolla millä hyvänsä huomiota keräävä media voi myös olla jopa fossiilisen öljybisneksen kokoinen hidaste ilmastoneutraalia planeettaa kohti kuljettaessa.

Suomen, jossa kansalaisten hiilijalanjälki on suuri mutta jossa osaamme kehittää erinomaisia ilmastoratkaisuja, on hyödyksi toimia suunnannäyttäjänä. Kirjoittajat listaavat Suomen mahdollisuuksia: puhdas energia, energiatehokkuus, puhtaat materiaalit, rakentamisen ja asumisen cleantech, puhdas vesi ja veden käytön tehokkuus, materiaali- ja ravinnekiertojen teknologiat ja järjestelmät, älykäs liikenne ja kulkemisen uudet ratkaisut, kestävä ruokajärjestelmä sekä suunnittelu ja asiantuntijapalvelut.

Tienhaarassa sopii monenlaiselle lukijalle. Se tarjoaa monipuolisesti tietoa ilmastoneutraaliin yhteiskuntaan siirtymisestä, ja sopii siksi myös oppikirjaksi. Suosittelen lämpimästä tutustumista kiihkottomaan mutta jämerään teokseen.

\section{ARTO O. SALONEN}

$K T$, apulaisprofessori Itä-Suomen yliopisto kasvatustieteen dosentti Helsingin yliopisto

sosiaalipedagogiikan dosentti Itä-Suomen yliopisto

kestävän kehityksen dosentti Maanpuolustuskorkeakoulu 